\title{
Investigating the effects of Iranian cultural factors on brand equity for strategic management of market share
}

\author{
Maryam Jahandoost ${ }^{*}$ and Solmaz Bahrami
}

MBA student at Payam-e Noor University, Damavand Branch, Damavand, Iran

\section{CH R O N I C L E}

Article history:

Received May 12, 2013

Received in revised format

12 September 2013

Accepted 6 October 2013

Available online

October 112013

Keywords:

Brand, Brand Equity

Strategic brand management

Iranian cultural factors

Philpa System Co. \begin{abstract}
A B S T R A C T
Brand is a symbol, logo and indicator of the specific identity of a product manufacturer and the services they render which can create value for both the manufacturer itself and the customers of those products and services. In this paper, we investigate the relationship between Iranian cultural factors with those creating brand value in this industry. The proposed study chooses Philpa System Co. as statistical population and the subject for our case study. The study chooses 56 people who had some past purchase experience from Philpa System as samples. A questionnaire was designed and distributed among the participants. The validity of which was confirmed through depth interviews made with experts of the pertinent industry and its reliability was also calculated using Cronbach's alpha test and was shown to be $82.4 \%$, which indicated the good reliability of these questionnaires. The data obtained from these questionnaires were analyzed using path analysis and structural equation modeling methods. The results gained from the investigations showed that different aspects of Iranian cultural factors, specifically customer honoring, had the greatest effect on the quality of customers' perception from the brand; it was also shown that promotion in any of the other aspects presented in Aaker's brand equity model will directly influence and increase the perceived quality of the brand.
\end{abstract}

\section{Introduction}

Brand plays an important role on the success of organizations and there are literally various definition for brand. One of the most acceptable definitions of a brand is presented by American Marketing Association (AMA , 2007) as "A name, phrase or term, sign, indicative mark or symbol, design or combination of them which aims to introduce a product or a new service." It is necessary to know that branding or brand, normally, is considered important not only for companies but also for consumers. In terms of consumers or customers' perspective, brand plays an important role for many

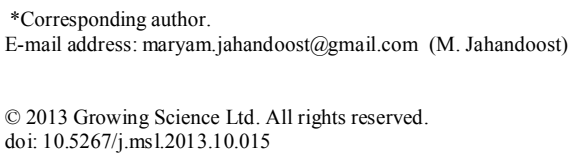


reasons. Brand for customers indicates sellers' commitment to quality and thereby reduces the time they may spend on deciding about the type of product or brand they should buy. Brand for firms indicates a sort of benchmark of quality as well as customer's expectation, a point of differentiation between competitors and a steady stream of profit (Keller et al., 2011).

During the past few decades, "brand equity" has now entered into marketing concept, describing and clarifying the relationship between the customer and the brand itself. The thing that plays essential role in keeping the brand equity is the process of strategic brand management, and the organization or company, which intends to invest on its own specific brand to publicize it in its target market. In customer marketing, brands often describe the points of differentiation among competitive services where different firms render, and this way, it becomes essential for the success of these firms (Wood, 2000). Therefore, strategic brand management is a necessary factor for building such a differentiation and keeping its constant effectiveness. It is worth to mention that identifying the strong points and clear opportunities for publicizing a brand in the competitive market plays essential role in developing the process of strategic brand management. In this paper, we focus on investigating the effects of cultural factors in Iran in creating brand equity and we study the impact on developing the strategic brand management. According to Doyle (1998) and Kapferer (2012), and to the brand pyramid and identity prism that they've offered, culture is introduced as the most effective element in the structure of brand and other elements presented in this pyramid, which influence this factor.

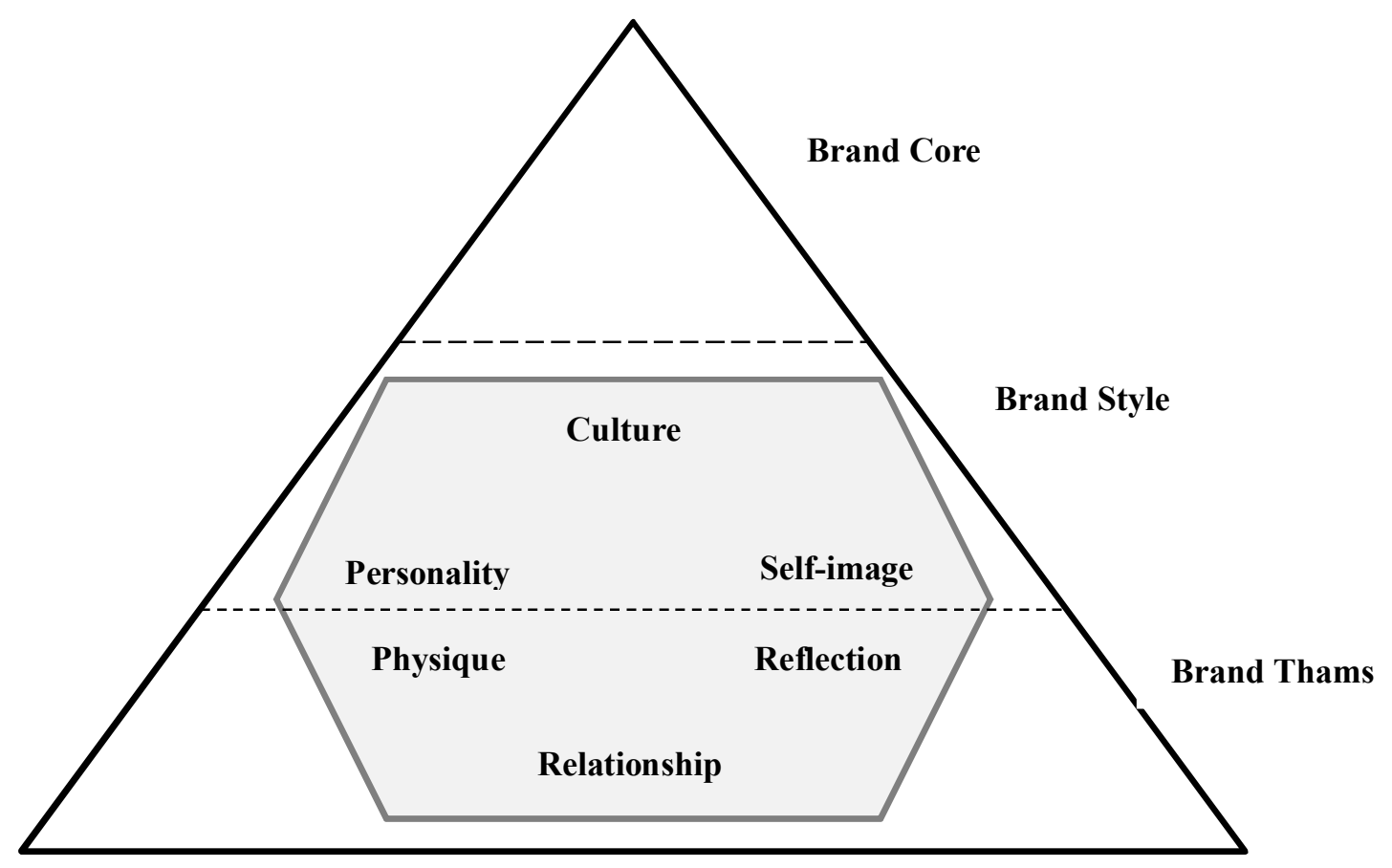

Fig. 1. The brand pyramid and the identity prism (Doyle , 1998)

Culture helps brand management and branding strategies develop the market, and enables the branding team to convey transferable concepts and messages through packaging and design, publication and other processes performed on the product (Doyle, 1998). The purpose of strategic brand management is, in fact, to design and to implement marketing plans and activities in order to create, to measure and to manage brand equity. According to the definition provided by Keller (1998), the stages of strategic brand management process are as follows: 1-identification and creation of brand equity and positioning 2- design, implementation and marketing the brand 3- measuring and analyzing the brand efficacy 4- development and stability of brand value. We look to find out the way each of these cultural factors are associated with brand equity and the degree of their effects to 
identify and to operationalize brand development strategies and to determine the required changes to resuscitate our brand so that the development and stability of it (the fourth stage of strategic brand management process) will be ensured. Different classifications were offered in literature for various methods of evaluating the brand equity; yet, in general, 3 approaches were the most common ones among other evaluation methods and were frequently studied by researchers as follows,

1.1- Financial model: Brand is evaluated according to financial indicators in these models.

1.2- Psychological and behavioral model: These models are based on consumer's perception.

1.3- Hybrid models: These models are combination of financial and psychological/behavioral models (Marcus , 2007).

As we may know, various evaluation models are known for these approaches, (Keller et al., 2011; Aaker, 1991). The model and the test used for this study are based on Aaker's brand equity model (1991). We have chosen this model because it is a well-known and valid one in branding field and other models are somewhat excerpted from this approach. In addition, many researchers have validated this model and empirically tested it in many different fields. This model is consisted of 5 aspects which are: 1- brand loyalty 2- perceived quality of the brand 3-brand associations 4- brand awareness 5- other features. In this paper, the relationship between Iranian cultural factors and the first 4 aspects was studied.

\section{Review of literature}

Various researches and studies were carried out on branding in different fields of manufacturing and service-rendering, and brand equity has been always a matter of high interest for researchers. In Iran, similar studies were also accomplished for the evaluation of banks, stock market, telecommunication companies, internet providers, post, etc. as it is clear from literature, brand equity has been exposed to little attention. Table 1 presents a list of several studies including brand association, awareness, perceived quality, and loyalty concepts.

\subsection{The Theoretical Framework and Conceptual Model of the Research}

Through depth interview and surveys accomplished with a number of experts of the office furniture manufacturing industry, some of the cultural factors, which were always emphasized on and have had determining role in customer's decision about buying a specific brand were identified in the form of 4 major indexes. The dependent factors affecting brand equity; the validity of these factors were tested and subsequently confirmed by exploratory and confirmatory factor analysis.

\section{Independent variables in the research}

- Psychological characteristics of buyers

- Suitability of the product with Iranian work culture

- Demographics

- Paying obeisance to customer

\section{Dependent variables in the research}

- Brand awareness

- Brand associations

- Perceived quality of the brand

- Brand loyalty

- Brand equity 
Table 1

A review of several researches done about brand equity in different organizations

\begin{tabular}{|c|c|c|}
\hline $\begin{array}{l}\text { Researcher } \\
\text { (year) }\end{array}$ & $\begin{array}{l}\text { Research goal/Methodology/Statistical } \\
\text { population }\end{array}$ & Results \\
\hline $\begin{array}{l}\text { Khosravi et al., } \\
2012\end{array}$ & $\begin{array}{l}\text { Identifying the specific aspects of brand equity } \\
\text { in Iranian insurance companies/ Brand Asset } \\
\text { Valuator model / descriptive statistics and t-test } \\
\text { / } 360 \text { insured Iranians }\end{array}$ & $\begin{array}{l}\text { The results of research indicate that the } \\
\text { degree of brand acceptance in one } \\
\text { insurance company has more effect } \\
\text { than brand power on the same } \\
\text { company, and the tendency toward the } \\
\text { brand have a greater effect on brand } \\
\text { acceptance than brand knowledge. }\end{array}$ \\
\hline $\begin{array}{l}\text { Ruževičiūt, \& } \\
\text { Ruževičius, } 2010\end{array}$ & $\begin{array}{l}\text { Preparation of consumers/ based on brand } \\
\text { equity evaluation model, theoretical data and } \\
\text { the results obtained from semi-structured } \\
\text { interview with Lithuanian brand experts and } \\
\text { questionnaire survey of enterprises / systemic } \\
\text { and comparative literature analysis / } 218 \\
\text { Lithuanian executive managers }\end{array}$ & $\begin{array}{l}\text { The research revealed that majority of } \\
\text { executive managers tend to associate } \\
\text { the concept of brand equity with } \\
\text { consumer approach. Attributes such as } \\
\text { brand awareness, perceived quality and } \\
\text { brand uniqueness were among the most } \\
\text { popular citation of respondents. }\end{array}$ \\
\hline $\begin{array}{c}\text { Rios \& } \\
\text { Riquelme, } 2008\end{array}$ & $\begin{array}{l}\text { Studying the effect of conventional approach in } \\
\text { evaluating the brand equity of online companies } \\
\text { / exploratory factor and confirmatory factor } \\
\text { analysis / } 1026 \text { Australian Bachelor and Masters } \\
\text { students }\end{array}$ & $\begin{array}{l}\text { Results confirmed the research } \\
\text { hypothesis and the identified influential } \\
\text { factors were: 1- value association 2- } \\
\text { brand loyalty } 3 \text {-brand awareness } 4- \\
\text { brand trust association and also } \\
\text { availability of being performed and } \\
\text { supported through web. }\end{array}$ \\
\hline Lin, 2006 & $\begin{array}{l}\text { Identifying the influential factors on the web } \\
\text { brand value in internet service providers/ 2- } \\
\text { variable and Pearson correlation / } 3000 \text { young } \\
\text { and middle-age users of Zoomerang Co. internet } \\
\text { services and hosting. }\end{array}$ & $\begin{array}{l}\text { Studying the obtained results, the major } \\
\text { influential factors such as brand } \\
\text { awareness, brand associations, brand } \\
\text { loyalty and perceived quality of the } \\
\text { brand, and minor factors like } \\
\text { interactions, services rendered to } \\
\text { customers and marketing } \\
\text { communications were identified. }\end{array}$ \\
\hline $\begin{array}{l}\text { Christodoulides } \\
\text { et al., } 2006\end{array}$ & $\begin{array}{l}\text { Identifying the influential factors on brand value } \\
\text { in retail service providers / semi-structural depth } \\
\text { interview and qualitative methods / } 16 \text { branding } \\
\text { experts }\end{array}$ & $\begin{array}{l}\text { Results identified factors such as } \\
\text { emotional relationships, online } \\
\text { shopping experience, rendered services, } \\
\text { performance, and trust to be effective } \\
\text { on brand equity of retail internet } \\
\text { service providers }\end{array}$ \\
\hline $\begin{array}{l}\text { Hatch \& Schultz, } \\
\quad 2001\end{array}$ & $\begin{array}{l}\text { Describing corporate branding as an } \\
\text { organizational tool / the case of British airways / } \\
\text { it's presenting a model to help managers analyze } \\
\text { context in terms of alignment between strategic } \\
\text { vision, organizational culture and corporate } \\
\text { image. }\end{array}$ & $\begin{array}{l}\text { The research shows that corporate } \\
\text { brands need to be managed in } \\
\text { proportion to the interplay between } \\
\text { vision, culture and images. This } \\
\text { requires effective dialogue between } \\
\text { high-ranking managers, external } \\
\text { stakeholders and members of the } \\
\text { organizational culture. }\end{array}$ \\
\hline $\begin{array}{l}\text { del Olmo \& } \\
\text { Munar, } 2009\end{array}$ & $\begin{array}{l}\text { Advancing the study and practice of hospitality } \\
\text { branding at a strategic level. it illustrates how } \\
\text { branding has been moving upwards and } \\
\text { becoming the core of the corporate strategy / the } \\
\text { case of Sol Melina }\end{array}$ & $\begin{array}{l}\text { This research shows that the } \\
\text { establishment of a proper brand } \\
\text { analysis and positioning demands a } \\
\text { focus on tourists' needs and wishes } \\
\text { determined through surveys, focus } \\
\text { groups, and quality assessment. }\end{array}$ \\
\hline
\end{tabular}




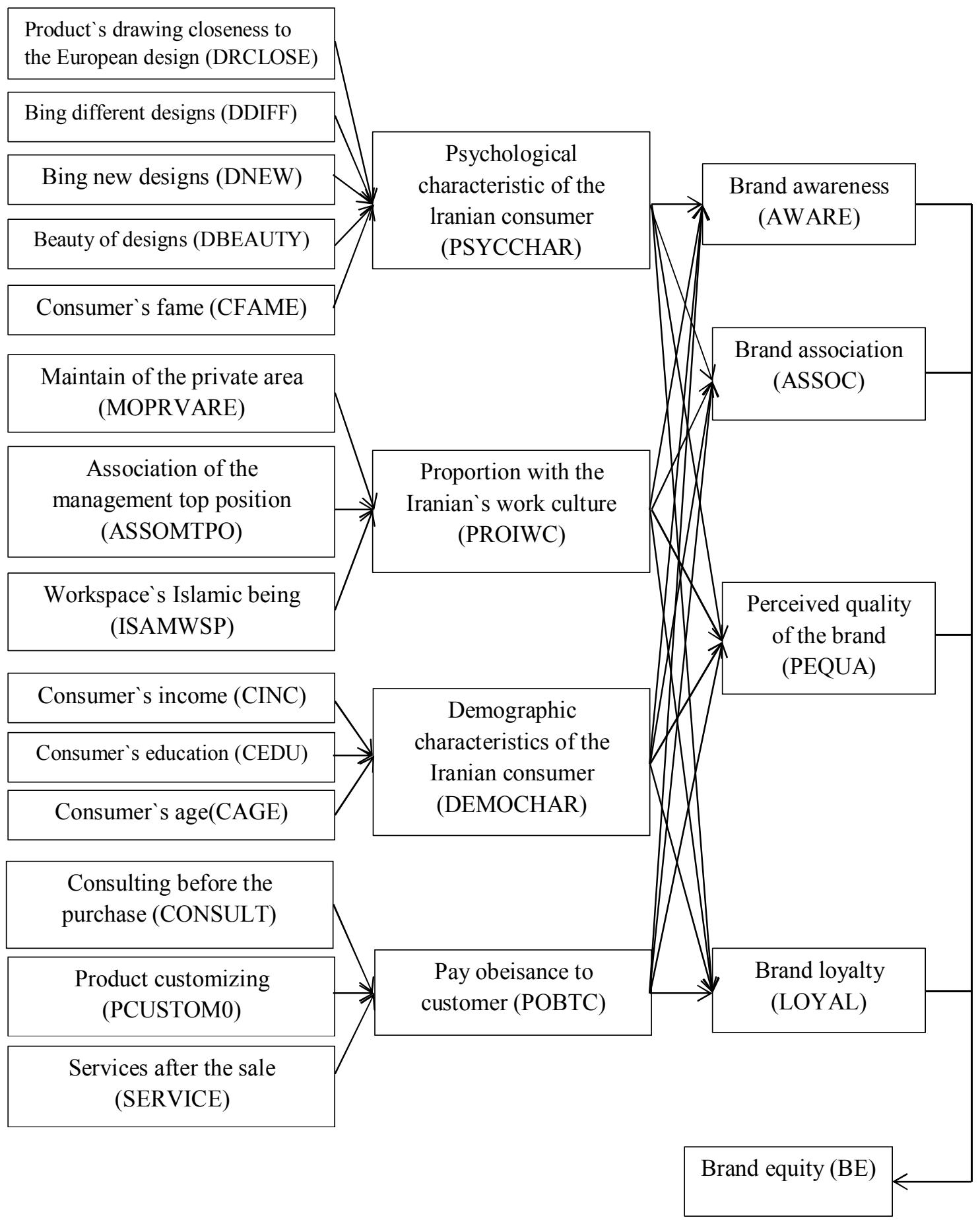

Fig. 2. Conceptual model of research

The conceptual definition of several technical terms and expressions used for branding are as follows,

Brand : it is a name, term, symbol or a design by which a seller or groups of sellers introduce and publicize their products and services, and thereby distinguish them from services of other competing producers (Keller, 2008).

Brand Equity : A collection of capabilities and associations of a brand which adds to or decreases the value of a product for its manufacturing company or customers. (Aaker \& Joachimsthaler, 2000). 
From customers' perspective (CBBE), regarding the brand equity, we can assert that each brand takes a positive equity when customers show desirable responses to the products and all marketing activities. Because of having higher brand equity, many customers indicate better reactions to brand generalization; on the other hand, a brand may have a negative equity when customers show unhappy responses to these marketing activities (Keller, 2008).

Brand Awareness: This is the potential ability of the buyer to recognize and to remember a purchased product. Brand awareness is an important and sometimes undervalued component of brand equity and can affect customers' perceptions and attitudes. It is perhaps better to say that brand awareness reflects the salience of the brand in the customers' mind. There are different forms of awareness, which basically include two main types:

1- Brand recognition: It is the ability of consumers to confirm their earlier encounters with a particular brand, which is under evaluation.

2- Recall: It is the ability of consumers to remember a brand which they've already met.

Brand Loyalty: This can be defined as a situation in which a customer is likely to substitute a brand with another one, especially when changes happen in its price or other aspects. Loyalty is a core dimension for brand equity and is more important than other measures, such as brand perceived quality and associations, which are often evaluated based upon their ability in influencing this index.

Brand Association: The key association component of brand equity usually involves image dimensions that are unique to a product class or to a brand. Association represents the basis for customers' decision to buy a brand (brand loyalty) and also create values for the manufacturing company and its customers (Aaker, 1991)

Perceived quality of the brand: It is one of the key aspects of brand equity. Perceived quality is to be associated with price premiums, brand usage and remarkable stock return. Furthermore, it's highly associated with other key brand equity measures, including specific functional benefit variables. Thus, perceived quality acts as a surrogate variable for other more specific elements of brand equity (Aaker, 1996)

The hypotheses of the research have two aspects :

A : the first four factors of Aaker's brand equity model are per se considered as research hypothesis :

A - 1: Brand awareness has a positive and significant impact on brand equity.

A -2 : Brand associations have positive and significant impact on brand equity.

A -3 : Perceived quality of the brand has a positive and significant impact on brand equity.

A -4 : Brand Loyalty has a positive and significant impact on brand equity.

B :

B - 1 : Psychological characteristics have a positive and significant impact on Brand Awareness.

B - 2 : Psychological characteristics have a positive and significant impact on Brand Associations.

B - 3 : Psychological characteristics have a positive and significant impact on the perceived quality of the brand.

B - 4 : Psychological characteristics have a positive and significant impact on Brand Loyalty.

B - 5 : Product's suitability with Iranian work culture has a positive and significant impact on Brand Awareness.

B - 6 : Product's suitability with Iranian work culture has a positive and significant impact on Brand Associations 
B - 7 : Product's suitability with Iranian work culture has a positive and significant impact on the perceived quality of the brand.

B - 8 : Product's suitability with Iranian work culture has a positive and significant impact on Brand Loyalty

B - 9 : Demographic characteristics have a positive and significant impact on Brand Awareness.

B - 10 : Demographic characteristics have a positive and significant impact on Brand Association

B - 11 : Demographic characteristics have a positive and significant impact on the perceived quality of the brand.

B - 12 : Demographic characteristics have a positive and significant impact on Brand Loyalty

B - 13: Customer honoring has a positive and significant impact on Brand Awareness.

B - 14 : Customer honoring has a positive and significant impact on Brand Association

B - 15 : Customer honoring has a positive and significant impact on the perceived quality of the brand.

B - 16 : Customer honoring has a positive and significant impact on Brand Loyalty.

\section{Methodology}

As we know, applied studies are accomplished to solve real and operational problems. In this paper, we have tried to evaluate the relationships between different aspects of brand equity in Aaker's model and cultural factors, which encourage Iranian customers to choose our brand, and also to examine the effect, each of these factors exert on each and any of the aspects presented in Aaker's model. Therefore, the present study is a practical research in terms of both its type and goal; in addition, since the results collected from the data were processed, this paper can be classified as a descriptivesurvey research as for its orientation. The statistic population chosen for this research was the consumers of Philpa System office furniture Company in Iran (being mostly organizations and legal personalities). Considering the fact that the mentioned products are of specific types and are mostly manufactured by customers' order, before finalization of the research, 30 people were selected as a sample and questionnaires were given to them. The method used for sampling was simple random sampling and for collecting information, an author-made questionnaire, inspired and combined from Aaker's standard questionnaire, with 5-point Likert scale, was used.

In order to evaluate the credibility and validity of the questionnaire, and in fact to confirm its accuracy and truthfulness, the credibility of the questionnaire was checked by several university professors and experts; furthermore, to confirm the truthfulness, we have exploited Exploratory Factor Analysis in order to evaluate the divergence validity. In other terms, Exploratory Factor Analysis is worth to be suggested as it can be used both for modeling and structuring. Besides, to test the measuring models and to ensure their accuracy (divergence validity), Confirmatory Factor Analysis was carried out. In addition, in order to study and to evaluate the reliability of the questionnaire, that is its capability to yield similar results if repeated in different contexts, Cronbach's alpha was used. The confidence coefficient obtained from this method was calculated using SPSS program and it was $82.4 \%$. This figure indicates that the questionnaire enjoys a good level of reliability. This research, in terms of hypothesis type, is considered a relational. In this study, 17 items were designed for evaluating the brand equity and 16 for Iranian cultural factors; the latent variables were confirmed using the exploratory factor analysis and then the accuracy of their models was discussed. Results obtained from exploratory factor analysis and confirmation of these results were respectively offered by SPSS and LISREL programs. In carrying out factor analysis, we should first ensure that the available data have the capability for the analysis. To ensure their capability, we have used Bartlett Test. This index ranges from 0 to 1 . In order to investigate whether or not the data are good and appropriate for factor analysis, there exist many diverse methods amongst which we can name Kaier-Meyer-Olkin (KMO), which always fluctuates between 0 and 1 . If the value of KMO is 
less than 0.50 , then the data would not be good for the analysis; if it is located between 0.50 and 0.69 , we have to execute the analysis with caution and if it is more than 0.70 , the existing correlation between the data will be appropriate for the factor analysis. It must be noted that the adequacy of sample size (KMO) is a statistic index determining the proportion of variance between two variables sharing a common variance. In addition, Bartlett's test of Sphericity done by SPSS for exploratory factor analysis of brand equity were respectively 0.780 and 0.000 and for exploratory factor analysis of Iranian cultural factors respectively 0.798 and 0.000 . Thus, it could be concluded that the data are good to be used in the factor analysis.

To carry out factor analysis with LISREL program, we should first check for the number of factors needed. To do so, we have to test these two hypotheses :

$H_{0}:$ One factor is enough

$H_{1}$ : One factor is not enough

To answer this question, we should study the Chi-Squared test and other criteria for the goodness of the model fitness. The less is the value of Chi-Square test, the better will be the results because this test shows the difference between the data and the model. The Goodness of Fit Index (GFI) and Adjusted Goodness of Fit Index (AGFI) must be over 90\%. The less is the value of ARMSE test, the better will be the result, since this reflects the Root Mean Square Error of the model. The output of the program indicates the goodness-of-fit for structural equation model (the ratio of $\chi^{2}$ to $\mathrm{df}$ is less than 3). Therefore, the value of $\chi^{2}$ is low and good. The results obtained from confirmatory factor analysis of brand equity show that ARMSE was 0.08 and it is less than the critical limit and is equal to 0.046 and the confirmatory factor analysis of Iranian cultural factors showed that ARMSE was 0.08 , which is less than the critical limit and equal to 0.056 . The above-mentioned indexes indicate the goodness-of-fit for structural equation model of the research. According to the results gained from confirmatory factor analysis, the resultant coefficients are significant because their statistical significance test values are bigger than 1.96 and lower than -1.96 . Thus, we can conclude that the 0 hypothesis is rejected, and in other terms, the observed data are to a great deal consistent with the conceptual model of the study.

In this research, to evaluate the factors influencing the brand equity, and to determine the coefficient of each variable affecting it, structural equation modeling method was used and it was carried out using LISREL program. In fact, this model aims at exploring direct and indirect effects of latent exogenous variables on indigenous ones. The structural equation model of research for standard estimation is illustrated in Fig. 1 as follows,

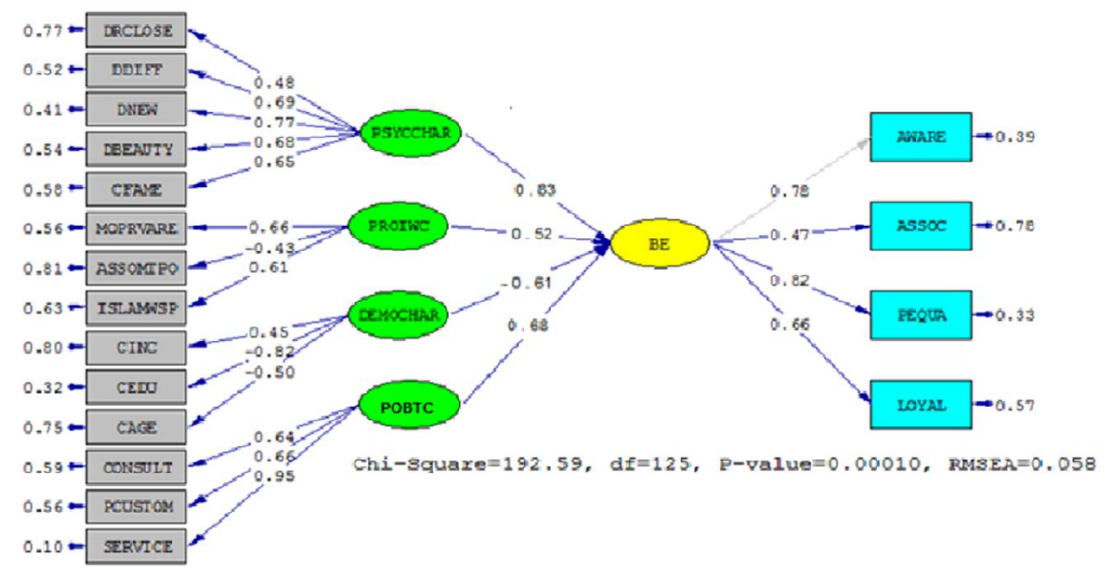

Fig. 1. The structural equation model of research for standard estimation 
Explanation: The grey arrow, linking brand equity to awareness, indicates the stability and constancy of brand awareness. In other terms, since brand equity is comprised from a combination of four aspects, the program finds the relationship of empowerment with the first aspect as fully significant and investigates those of other aspects.

In this research, we are seeking for the following major hypotheses:

$\mathrm{H}_{1}$ : Psychological characteristics have positive and meaningful effect on brand equity

$\mathrm{H}_{2}$ : Suitability with Iranian working culture has positive and meaningful effect on brand equity

$\mathrm{H}_{3}$ : Demographic features have positive and meaningful effect on brand equity

$\mathrm{H}_{4}$ : Paying obeisance to customer has positive and meaningful effect on brand equity

\section{Results and Discussion}

Results obtained from research hypotheses indicate the conformability of the first, second and fourth hypotheses of the study; in other terms, psychological characteristics of the consumer, suitability of the product with Iranian work culture, and customer honoring have positive and meaningful effects on brand equity. However, the third factor has a negative factor loading and therefore, the third hypothesis is rejected. Yet, this variable is also meaningful and has negative effect on brand equity. In other terms, demographic features will have an inverse effect on brand equity. From the results obtained through testing research hypotheses and demographic diagrams, it becomes clear that the main target audiences of our products are the youth having high school and university education (bachelor and masters). Other findings of the model indicate that associating the top position of management also has a negative and meaningful effect on product suitability with Iranian work culture. Thus, we can say that associating the top position of management cannot act in accordance with the Iranian work culture and in fact, the main cause of attracting young customers' attention is the novelty of products, their fantastic designs, and the differences they have with old conventional ones. The one-way average test done on brand equity and its aspects and on Iranian cultural factors, indicated that the association factor, having a 4.16 average and 0.66 standard deviation, and the customer honoring factor with 4.11 average and 0.71 standard deviation yielded the best results among Iranian cultural factors. Generally, all of the aspects studied for both equity and cultural factors, had averages more than 3 , and thus all proved to be good. Results achieved from regression analysis, show that Iranian cultural factors had the greatest effect on the perceived quality of the brand, and promoting each of other aspects of brand equity presented in Aaker's model, in this industry, will directly result in the reinforcement of the perceived quality of the brand. It is worth to mention that customer honoring, enjoying the highest standard $\beta$ coefficient, has the greatest effect on the perceived quality among other Iranian cultural factors. A more concise study on the regression analysis divulges the fact that psychological characteristics of consumers have a fully significant and strong effect on the aspects of brand equity presented in Aaker's model. This evidences the aesthetic sensibility and trans-regional view of Iranian customers. In conclusion, according to the investigations carried out, in order to maintain and enhance the competitive position in the market, we should focus strategic brand management process on the quality of our relationship with customers. We also need to identify their tastes and latent requirements, and to innovate products, which comply with their taste, and thus, increase their loyalty to our brand and our stability in the competitive market. POBTC (Paying Obeisance To Customer) is amongst the factors which has nowadays become the matter of concern in many occupations. Yet, its effectiveness in choosing the approach administered for strategic brand management should be exposed to more precise investigations. The final model of the research is illustrated in Fig. 3. The bold red, black, and dotted lines shown in this model respectively indicate 1- a strong and positive, 2- a mediocre, and 3- a weak and in some cases a negative and inverse effectiveness and relationship between the aspects being studied. 


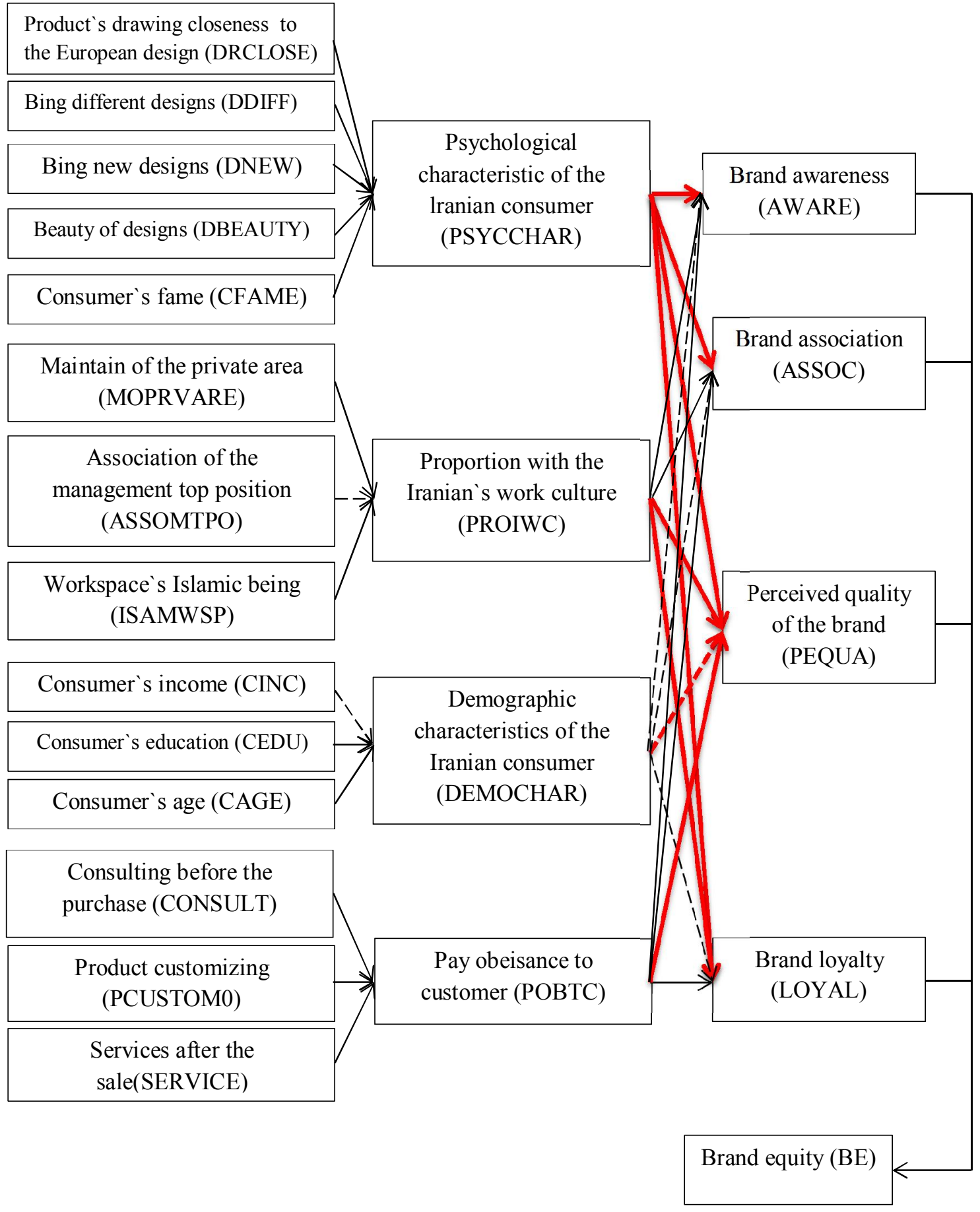

Fig. 3. Research final model

\section{Suggestions}

Now that we have understood the full-scale and strong relationship of psychological characteristics of consumers with brand equity, and also we have figured out that Iranian cultural factors, in particular customer honoring, have the greatest effect on the perceived quality of the brand, we suggest that customer honoring be precisely investigated with regards to the factors affecting it; to do this, a specific managing approach should be administered. In the industry of office furniture, we confront two important aspects alongside each other: being practical and luxurious; thus paying obeisance to 
customer and attention to his perception of beauty, and thereby attempting to manufacture versatile products according to his/her taste, are mandatory for the survival of the company. Considering the fact that the quality perceived from the brand for products which are merely practical or merely luxurious is different from those enjoying both aspects at the same time, we should pay more profound attention in applying the above-mentioned strategy. Generally, we suggest that manufacturers pay special attention to the taste and social position of customers and customize their products in accordance with their demands. It is also suggested that target markets be divided into different categories and customers be studied at different levels and in different groups; thus, the various methods applied for attracting customers' attention should be adjusted and each group should be treated according to their specific common features. Using market concentration strategies, and at the same time introducing various and versatile designs to specific markets, would be more beneficial and economical to this industry. We suggest other researchers to study brand value creation approaches and branding factors in other manufacturing and service industries and present a localized model conforming to the cultural needs of each society, since culture is considered as one of the most influential factors in customers and consumers' criteria for choosing a specific product or service.

\section{Acknowledgement}

We hereby express our deepest gratitude toward the benign manager of Philpa System Co. and toward the most valued professors at Payam-e Noor University, Damavand branch, specifically our dear Professor Dr. Yashar Salamzadeh, and all others who have helped us unfailingly with their consultations and constructive opinions. We would like to wish them all success in their future endeavors.

\section{References}

Aaker, D. A. (1996). Measuring brand equity across products and markets. California Management Review, 38(3), 103.

Aaker, D. A. (1991). Managing Brand Equity. The Free Press, New York, NY.

Aaker, D. A. ( 1996). Building Strong Brands. The Free Press, New York, NY.

Aaker, D. A., \& Joachimsthaler, E. (2000). The brand relationship spectrum.California Management Review, 42(4), 8-23.

Christodoulides, G., De Chernatony, L., Furrer, O., Shiu , E., \& Abimbola , T. ( 2006 ). Conceptualizing and measuring the equity of online brands. Journal Of Marketing Management, $22,799-825$.

Davis, S. (1995). A vision for the year 2000: Brand asset management. Journal Of consumer Marketing, 12(4), 65-82.

Doyle, P. (1998 ), Marketing Management And Strategy, Prentice Hall, London.

Hatch, M. J., \& Schultz, M. (2003). Bringing the corporation into corporate branding. European Journal of Marketing, 37(7/8), 1041-1064.

Kapferer, J. N. (2012). The new strategic brand management: Advanced insights and strategic thinking. Buy now from Kogan Page.

Keller, K. L., Parameswaran, M. G., \& Jacob, I. (2011). Strategic brand management: Building, measuring, and managing brand equity. Pearson Education India.

Khosravi, S., Shafei, R., \& Salavati, A. (2012). Survey of the Effective Dimension In Improvement of Brand Equity In Iranian Insurance Companies.Interdisciplinary Journal of Contemporary Research in Business, 3(10). 672 - 685.

Kotler, P ., \& Keller, K. L. (2007). Marketing Management, 12, Prentice Hall, NJ.

Lin, Y. J. (2006). Toward the Understanding of Web Equity on an E-commerce Website. California State University, Fullerton.

Maurya, U. K., \& Mishra, P. (2012). What is a brand? A Perspective on Brand Meaning. European Journal of Business and Management, 4(3), 122-133. 
del Olmo, L., \& Munar, A. M. (2009). Strategic branding in hospitality: The case of Sol Meliá. Bridging Tourism Theory and Practice, 1, 219-232.

Ruževičiūtè, R., \& Ruževičius, J. (2010). Brand equity integrated evaluation model: consumer-based approach. Economics and Management, 15, 719-725.

Rios, R. E., \& Riquelme, H. E. (2008). Brand equity for online companies.Marketing Intelligence \& Planning, 26(7), 719-742.

Wood, L. (2000). Brands and brand equity: definition and management. Management decision, 38(9), 662-669.

Zeithaml, V. A. (1998). Consumer perceptions of price, quality and value : A means-end model and synthesis of evidence. Journal of Marketing, 52, 2 -22. 